\title{
Telomerase as a therapeutic target for malignant gliomas
}

\author{
Tadashi Komata $^{1,2}$, Takao Kanzawa ${ }^{2}$, Yasuko Kondo ${ }^{1,2}$ and Seiji Kondo ${ }^{* 1,2}$ \\ ${ }^{1}$ The Center for Surgery Research, The Cleveland Clinic Foundation, Cleveland, Ohio, OH 44195, USA; ${ }^{2}$ The Department of \\ Neurosurgery, The Mount Sinai School of Medicine, New York, NY 10029, USA
}

Telomerase, a ribonucleoprotein enzyme, is considered as a potential target of cancer therapy because of its preferential expression in tumors. In particular, malignant gliomas are one of the best candidates for telomerasetargeted therapy. It is because malignant gliomas are predominantly telomerase-positive, while normal brain tissues do not express telomerase. In theory, there are two telomerase-associated therapeutic approaches for telomerase-positive tumors. One approach is the antitelomerase cancer therapy to directly inhibit telomerase activity, resulting in apoptotic cell death or growth arrest. Two major components of the telomerase holoenzyme complex, the RNA template (hTER) and catalytic subunit (reverse transcriptase, hTERT) are well considered as therapeutic targets. The other approach is the telomerasespecific cancer therapy by targeting telomerase-expressing tumor cells as a means to directly kill the cells. Strategies using the transfer of therapeutic gene under the hTERT promoter system as well as immunotherapy directed against telomerase-positive cells are generally included. These telomerase-associated therapies are very promising for the treatment of malignant gliomas.

Oncogene (2002) 21, 656-663. DOI: $10.1038 / \mathrm{sj} /$ onc/ 1205072

Keywords: telomerase; telomerase RNA; telomerase reverse transcriptase; apoptosis; glioma

\section{Introduction}

Gliomas are histologically classified into four grades (Grades I, II, III, and IV of World Health Organization). Grades I and II indicate low-grade glioma, and Grades III (anaplastic astrocytoma, AA) and IV (glioblastoma multiforme, GBM) are malignant glioma (Burger et al., 1985). Surgery, radiotherapy, chemotherapy, and immunotherapy are currently representative treatment modalities for patients with gliomas (Davis et al., 1999). Advances in these therapies extended the prognosis for patients with low-grade glioma from 5 years to 10 years over the time period of 1984-1995 (Piepmeier and Christopher, 1997). The most malignant type, GBM represents $29 \%$ of all

*Correspondence: S Kondo, The Department of Neurosurgery, The Mount Sinai Medical Center, One Gustave L Levy Place, Box 1136, New York, NY 10029-6574, USA; E-mail: Seiji.Kondo@mssm.edu primary brain tumors or 5000 new cases per year in the United States (Mahaley et al., 1989). The prognosis for patients with GBM is very poor, with a median survival rate of less than a year and a 5-year survival rate of 5\% or less (Schoenberg, 1983; Mahaley et al., 1989; Deen et al., 1993). No therapeutic modality has substantially changed the outcome of patients with GBM (Mahaley et al., 1989; Deen et al., 1993). Therefore, in order to improve the prognosis in this invariably fatal disease, it is imperative to explore novel therapeutic modalities.

\section{Telomerase in malignant gliomas}

Telomerase, a ribonucleic acid-protein complex, adds hexameric repeats of 5'-TTAGGG-3' to the ends of telomeres to compensate for the progressive loss (Blackburn, 1991; Counter et al., 1992; de Lange, 1994). Telomerase activity, which is generally undetectable in normal somatic cells, is expressed in approximately $90 \%$ of tumors (Kim et al., 1994; Broccoli et al., 1995; Hiyama et al., 1995). In malignant gliomas, telomerase activity is very often detected (Table 1) (Langford et al., 1995; DeMasters et al., 1997; Sallinen et al., 1997; Sano et al., 1998; Kleinschmidt-DeMasters et al., 1998; Chong et al., 1998; Hiraga et al., 1998; Le et al., 1998; Weil et al., 1999; Carroll et al., 1999; Falchetti et al., 1999; Huang et al., 1999; Kleinschmidt-DeMasters et al., 2000; Harada et al., 2000). In Grade I or II of gliomas, telomerase activity is detected in $0 \%$ or 0 to $33 \%$, respectively. In malignant gliomas, telomerase is positive in 10 to $100 \%$ of anaplastic astrocytomas and in 26 to $100 \%$ of GBM. Although the ratio of telomerase-positive cells in gliomas varies, most of the reports show that the incidence of telomerase expression is closely correlated with the malignancy, and telomerase is detected in the vast majority of malignant gliomas. By contrast, normal brain tissues do not express telomerase activity (DeMasters et al., 1997; Le et al., 1998; Huang et al., 1999; Harada et al., 2000), while telomerase is detectable only in human embryonic neural precursor cells at low levels (Ostenfeld et al., 2000). Therefore, telomerase is expected to represent a very good candidate not only for the useful prognostic and diagnostic marker of malignant gliomas, but also for the targeted therapy of malignant gliomas. There are theoretically two approaches as telomerase-asso- 
Table 1 Ratio of telomerase-positive tumors in malignant gliomas histologically classified

\begin{tabular}{|c|c|c|c|c|c|}
\hline Normal brain tissues (\%) & Grade I $(\%)$ & Grade II $(\%)$ & Grade III (AA) (\%) & Grade IV (GBM) (\%) & References \\
\hline & & $2 / 20(10)$ & $38 / 51(75)$ & & Langford et al., 1995 \\
\hline \multirow[t]{6}{*}{$0 / 8(0)$} & & $0 / 2(0)$ & $2 / 8(25)$ & $10 / 19(53)$ & DeMasters et al., 1997 \\
\hline & & $1 / 1(100)$ & & $4 / 6(67)$ & Sallinen et al., 1997 \\
\hline & & $0 / 8(0)$ & $0 / 3(0)$ & $3 / 6(50)$ & Sano et al., 1998 \\
\hline & & & $2 / 3(67)$ & $11 / 11(100)$ & Kleinschmidt-Demasters et al., 1998 \\
\hline & $0 / 16(100)$ & $3 / 13(23)$ & $3 / 13(23)$ & $10 / 38(26)$ & Chong et al., 1998 \\
\hline & $0 / 3(0)$ & $3 / 15(20)$ & $6 / 15(40)$ & $34 / 47(72)$ & Hiraga et al., 1998 \\
\hline \multirow[t]{4}{*}{$0 / 4(0)$} & & $3 / 9(33)$ & $5 / 11(45)$ & $36 / 41(88)$ & Le et al., 1998 \\
\hline & & & $3 / 3(100)$ & $3 / 3(100)$ & Weil et al., 1999 \\
\hline & & $0 / 4(0)$ & & $7 / 25(28)$ & Carroll et al., 1999 \\
\hline & & $0 / 4(0)$ & $3 / 11(27)$ & $25 / 30(83)$ & Falchetti et al., 1999 \\
\hline \multirow[t]{2}{*}{$0 / 2(0)$} & & $10 / 12(83)$ & $10 / 10(100)$ & $11 / 11(100)$ & Huang et al., 1999 \\
\hline & & & $1 / 1(100)$ & $16 / 18(89)$ & Kleinschmidt-Demasters et al., 2000 \\
\hline $0 / 1(0)$ & & & & $26 / 42(62)$ & Harada et al., 2000 \\
\hline
\end{tabular}

World Health Organization Grade. Low grade astrocytoma (Grade I or II). AA, anaplastic astrocytoma (Grade III). GBM, glioblastoma multiforme (Grade IV)

ciated therapy for malignant gliomas. One is the antitelomerase cancer therapy to directly inhibit telomerase activity, resulting in induction of cell death or growth arrest. The other is the telomerase-specific cancer therapy by targeting telomerase-positive cells as a means to directly kill the cells.

\section{Anti-telomerase cancer therapy}

Telomerase has two major components and several associated proteins that are essential for proper function (Feng et al., 1995; Harrington et al., 1997; Meyerson et al., 1997; Nakayama et al., 1997; Nakamura et al., 1997). The first major component is the human telomerase RNA (hTER) to serve as the template on which telomeric repeats are added to the ends of the chromosomes (Feng et al., 1995). The second major component is the human telomerase reverse transcriptase (hTERT) catalytic subunit (Meyerson et al., 1997; Nakamura et al., 1997). The ability of cells to express telomerase activity is predominantly regulated at the transcriptional level of hTERT in cells (Takakura et al., 1999; Cong et al., 1999). The hTER and hTERT have been mainly used as therapeutic targets so far (Table 2).

\section{Construct expressing an antisense transcript}

The hTER is divided into several domains that are essential for normal enzymatic function and assembly of the telomerase enzyme (Betts et al., 1995; Gilley and Blackburn, 1996; Tzfati et al., 2000). Feng et al. (1995) demonstrated that introduction of a construct expressing an antisense transcript to the first 185 nucleotides of the RNA induced cell death in HeLa cells after 23-26 doublings. The clones that underwent crisis had reduced telomerase activity and shortened telomeric DNA. Using the same construct, malignant glioma U251MG cells underwent apoptosis or differentiation after 30 doublings following telomerase inhibition (Kondo et al., 1998a). These findings indicate that inhibition of telomerase function induced antitumor effect.

\section{2-5A antisense system}

A 5'-phosphorylated, 2', 5'-linked oligoadenylate (2$5 \mathrm{~A}$ ) is required to activate the catalytic activity of RNaseL (Silverman, 1997). 2-5A-antisense chimeras contain 2-5A covalently attached through butanediol phosphate linkers to antisense oligonucleotide. In nature, RNaseL functions as a component of the $2-$ $5 \mathrm{~A}$ system, implicated in the antiviral activity of interferon (IFN) against picornavirus, vaccinia virus, and reovirus (Silverman, 1997). In the $2-5 \mathrm{~A}$-antisense approach, RNaseL is converted to a highly specific endoribonuclease capable of selectively cleaving individual RNA targets. When applied to HeLa cells, $2-$ $5 \mathrm{~A}$-antisense resulted in the ablation of PKR mRNA and enzymatic activity effectively blocking dsRNA activation of transcription factor NF- $\kappa \mathrm{B}$ (Maran et al., 1994). Because RNaseL is present in most mammalian cells, it is clear that the application of this technology is a powerful method for controlling gene expression. Recently, 2-5A antisense strategy has been applied to degrade hTER specifically and effectively (Kondo et al., 1998b). An antisense oligonucleotide against hTER linked to $2-5 \mathrm{~A}$ (2-5A-anti-hTER) in the presence of cationic liposome reduced the viability of human malignant glioma cells to $20-43 \%$ within 4 days through induction of caspase-dependent apoptosis (Mukai et al., 2000; Komata et al., 2000). Similar antitumor effects of 2-5A-anti-hTER were demonstrated in prostate cancer, ovarian cancer, and bladder cancer cells (Kondo et al., 2000; Kushner et al., 2000; Koga et al., 2001a). In contrast, cultured astrocytes, endothelial cells, or fibroblasts lacking telomerase were resistant to the 2-5A-anti-hTER treatment. Furthermore, treatment of subcutaneous or intracranial tumors in nude mice with the frequent intratumoral injections of 2-5A-anti-hTER was therapeutically effective (Kondo et al., 1998b; Mukai et al., 2000; Koga et al., 2001a). 2-5A-anti-hTER also enhanced the in vitro and in vivo antitumor effect of cisplatin or the recombinant adenovirus bearing the tumor suppressor p53 gene (Ad5CMV-p53) on malignant glioma 
Table 2 Components of telomerase as a target of anti-telomerase cancer therapy

\begin{tabular}{|c|c|}
\hline Components & References \\
\hline \multicolumn{2}{|l|}{ RNA component of telomerase (hTER) } \\
\hline Construct expressing an antisense transcript & Feng et al., 1995; Kondo et al., 1998a; \\
\hline $2-5 \mathrm{~A}$ antisense system & $\begin{array}{l}\text { Kondo et al., 1998b, 2000, 2001; Komata et al., 2000; } \\
\quad \text { Kushner et al., 2000; Mukai et al., 2000; Koga et al., 2001a }\end{array}$ \\
\hline Hammerhead ribozymes & Mukai et al., 2000; Yokoyama et al., 1998 \\
\hline Peptide nucleic acids & Norton et al., 1996; Shammas et al., 1999 \\
\hline 2'-O-MeRNA oligomers & Agarwal et al., 1997; Pitts et al., 1998; Herbert et al., 1999 \\
\hline \multicolumn{2}{|c|}{ Telomerase catalytic subunit (reverse transcriptase, hTERT) } \\
\hline Dominant negative hTERT & Hahn et al., 1999; Zhang et al., 1999 \\
\hline Reverse transcriptase inhibitors & $\begin{array}{l}\text { Strahl and Blackburn, 1994, 1996; Melana et al., 1998; } \\
\quad \text { Multani et al., 1998; Tejera et al., } 2001\end{array}$ \\
\hline Hammerhead ribozymes & Yokoyama et al., 2000; Ludwig et al., 2001 \\
\hline
\end{tabular}

cells (Komata et al., 2000; Kondo et al., 2001). Therefore, targeting telomerase RNA with 2-5Aanti-hTER is expected to represent an effective and novel approach for the treatment of telomerase-positive tumors including malignant gliomas as a single or combined regimen. However, the effect of $2-5 \mathrm{~A}$-antihTER is telomere length-independent (unpublished data) and is contrary to the widely perceived need for an extensive lag phase (dependent on telomere length) prior to the induction of cellular senescence or apoptosis. Therefore, the precise molecular mechanisms underlying the antitumor effect of 2-5A-anti-hTER need to be determined.

\section{Hammerhead ribozymes}

Ribozymes are catalytic antisense RNAs that cleave RNA substrates in a sequence-specific manner (Cech et al., 1981). The hammerhead-type ribozyme was originally discovered in satellite RNA of tobacco ringspot virus (Buzayan et al., 1986). Recent investigations reported that a hammerhead ribozyme targeting hTER reduced telomerase activity against tumor cells (Kanazawa et al., 1996; Yokoyama et al., 1998), although no change in proliferation rate was observed. Furthermore, a hammerhead ribozyme cleaves hTERT mRNA and inhibits telomerase activity (Yokoyama et al., 2000; Ludwig et al., 2001). Ribozyme cleavage of hTERT mRNA not only led to shortened telomere length and induction of apoptosis, but also sensitized tumor cells to inhibitors of topoisomerase (Ludwig et al., 2001). These results demonstrate a hammerhead ribozyme approach for anti-telomerase cancer therapy and suggest the possibility that it might be combined advantageously with topoisomerase-directed chemotherapy.

\section{Peptide nucleic acids}

The major problems with the oligonucleotide approach are that of stability and uptake common to oligonucleotide therapeutics. Peptide nucleic acids (PNAs) are modified oligonucleotides that contain a non-ionic backbone in which the deoxyribose linkages have been replaced by $\mathrm{N}$-(2-amino-ethyl) glycine units, making them resistant to degradation by endo- and exonucleases. Telomerase activity was inhibited in cells in culture by PNAs complementary to the hTER (Norton et al., 1996). When PNAs against hTER were coelectroporated into immortal human cells, the cells showed reduced telomerase activity, shortened telomeres, reduced colony size, and arrested cell proliferation after a lag period of 5-30 cell generations, consistent with suppression of their immortality (Shammas et al., 1999). Because the membrane permeability of PNAs is not high, strategies to facilitate in vivo uptake are expected.

\section{2'-O-me RNA oligomers}

2'-O-methyl-RNA (2'-O-meRNA) oligomers bind more tightly to complementary RNA sequences than do analogous DNA oligomers and have improved resistance to degradation by nucleases, reducing the need for phosphorothioate linkages and improving the selectivity of antisense effects (Agarwal et al., 1997). 2'-O-meRNA oligomers inhibited telomerase in prostate cancer cells with potencies superior to those possessed by analogous peptide nucleic acids (PNAs) (Pitts and Corey, 1998). Additionally, 2'-O-meRNA oligomers inhibited telomerase, leading to progressive telomere shortening and causing immortal human breast epithelial cells to undergo apoptosis with increasing frequency until no cells remain (Herbert et al., 1999). These results indicate the feasibility of using 2'-O-meRNA oligomers for the treatment of telomerase-positive tumors.

\section{Dominant-negative hTERT}

Recently, two groups have reported that direct inhibition of hTERT was achieved by introduction of dominant-negative versions of hTERT that are mutated at critical amino acid residues within the catalytic domain (Hahn et al., 1999; Zhang et al., 1999). When introduced into tumorigenic human cell lines, these mutants virtually abolished telomerase activity, presumably by competing for binding to other components of the telomerase holoenzyme complex that are essential for catalysis. Loss of telomerase activity led to a reduction in telomere length and an induction of apoptosis that occurred only when telomeres became critically short. Hahn et al. (1999) have also noted that 
Table 3 Telomerase-specific cancer therapy

\begin{tabular}{ll}
\hline System & References \\
\hline hTERT promoter & \\
$\quad$ caspase-8 & Koga et al., 2000 \\
bax & Gu et al., 2000 \\
diphtheria toxin A & Abdul-Ghani et al., 2000 \\
TK & Majumdar et al., 2001 \\
rev-caspase-6 & Komata et al., 2001 \\
FADD & Koga et al., 2001b \\
Immunotherapy & \\
hTERT-derived peptides & Vonderheide et al., 1999; Minev et al., 2000; Arai et al., 2001 \\
$\quad$ TERT RNA-transfected dendritic cells & Nair et al., 2000 \\
\hline
\end{tabular}

telomerase-inhibited human cell lines are unable to form tumors when injected into immunodeficient nude mice. The application of dominant-negative hTERT is promising to inhibit telomerase activity.

\section{Reverse transcriptase inhibitors}

Because the hTERT protein is a reverse transcriptase, several reverse transcriptase inhibitors have been tested as telomerase inhibitors (Strahl and Blackburn, 1996). Nucleotide analogs such as 3'-azido-3'-deoxythymidine (AZT) can be preferentially incorporated into DNA and result in chain termination. AZT has been the most extensively studied among reverse transcriptase inhibitors and has been shown to cause telomere shortening in Tetrahymena (Strahl and Blackburn, 1994). AZT inhibited telomerase activity and suppressed the growth of breast cancer cells (Melana et al., 1998). Additionally, AZT induced a rapid telomere shortening in melanoma or breast cancer cells (Multani et al., 1998). Interestingly, AZT-treated tumor cells have a reduced tumorigenicity in syngeneic BALB/c mice (Tejera et al., 2001). Tumor incidence was reduced and survival was prolonged in animals inoculated with AZT-treated cells when comparing with control counterparts. The number and size of spontaneous metastases were also decreased in animals inoculated with AZT-treated cells. Further investigation is needed to produce more potent telomeretargeting reverse transcriptase inhibitors with tolerable toxicity profiles.

\section{Potential problems with anti-telomerase cancer therapy}

There are several considerations about anti-telomerase cancer therapy. First, induction of apoptosis or growth arrest is considered to take place when telomeres shorten to a certain critical length. Therefore, there will be an expected lag phase between when telomerase is inhibited and the time when the telomeric DNA of tumor cells shorten sufficiently to produce detrimental effects on growth. This lag phase is about 30 doublings or one month in malignant glioma U251-MG cells (Kondo et al., 1998a), indicating that the antitumor effects may not occur until one month after telomerase activity is inhibited. Therefore, it is clear that simply inhibiting telomerase may not result in the anticancer effects that were originally hypothesized when tumors with long telomeres are treated. Because 2-5A-antihTER functions in a telomere length-independent manner, its application is expected to abolish the time lag. Recently, it has been shown that some tumor cells undergo p53- and the ataxia telangiectasia mutated (ATM) kinase-dependent apoptosis $48 \mathrm{~h}$ after inhibition of the telomeric-repeat binding factor 2 (TRF2) (Karlseder et al., 1999). It indicates that telomeres lacking TRF2 directly signal apoptosis, possibly because they resemble damaged DNA. These telomere length-independent approaches are promising to treat tumors with long telomeres. Second, tumor cells may become resistant to telomerase inhibitors or acquire alternative mechanisms of telomere maintenance independent of telomerase during the treatment. Lastly, it is likely that inhibitors of telomerase may damage normal cells expressing telomerase such as hematopoietic stem cells, germ cells or activated $\mathrm{T}$ cells (Chiu et al., 1996; Weng et al., 1996; Wright et al., 1996; Ramakrishnan et al., 1998). However, these side effects might be minor because stem cells of renewal tissues typically have longer telomeres than tumor cells have and the stem cells only proliferate intermittently and their telomerase activity is negligible during quiescence (White et al., 2001).

\section{Telomerase-specific cancer therapy}

Recently, there have been reported two types of exciting investigations by targeting telomerase-positive cells as a means to directly kill the cells (Table 3). First, the promoter of hTERT gene is used to restrict the expression of suicide gene or toxin to telomerasepositive tumor cells (Koga et al., 2000, 2001b; Gu et al., 2000; Abdu-Ghani et al., 2000; Majumdar et al., 2001; Komata et al., 2001). Second, immunotherapy directed against telomerase-positive cells is developed (Vonderheide et al., 1999; Minev et al., 2000; Nair et al., 2000; Arai et al., 2001). Using hTERT-derived peptides or hTERT RNA, cytotoxic T cell responses and tumor immunity are elicited. Because normal cells lacking telomerase activity are kept intact, these approaches are expected as a promising targeting approach for the treatment of tumors with telomerase activity. 


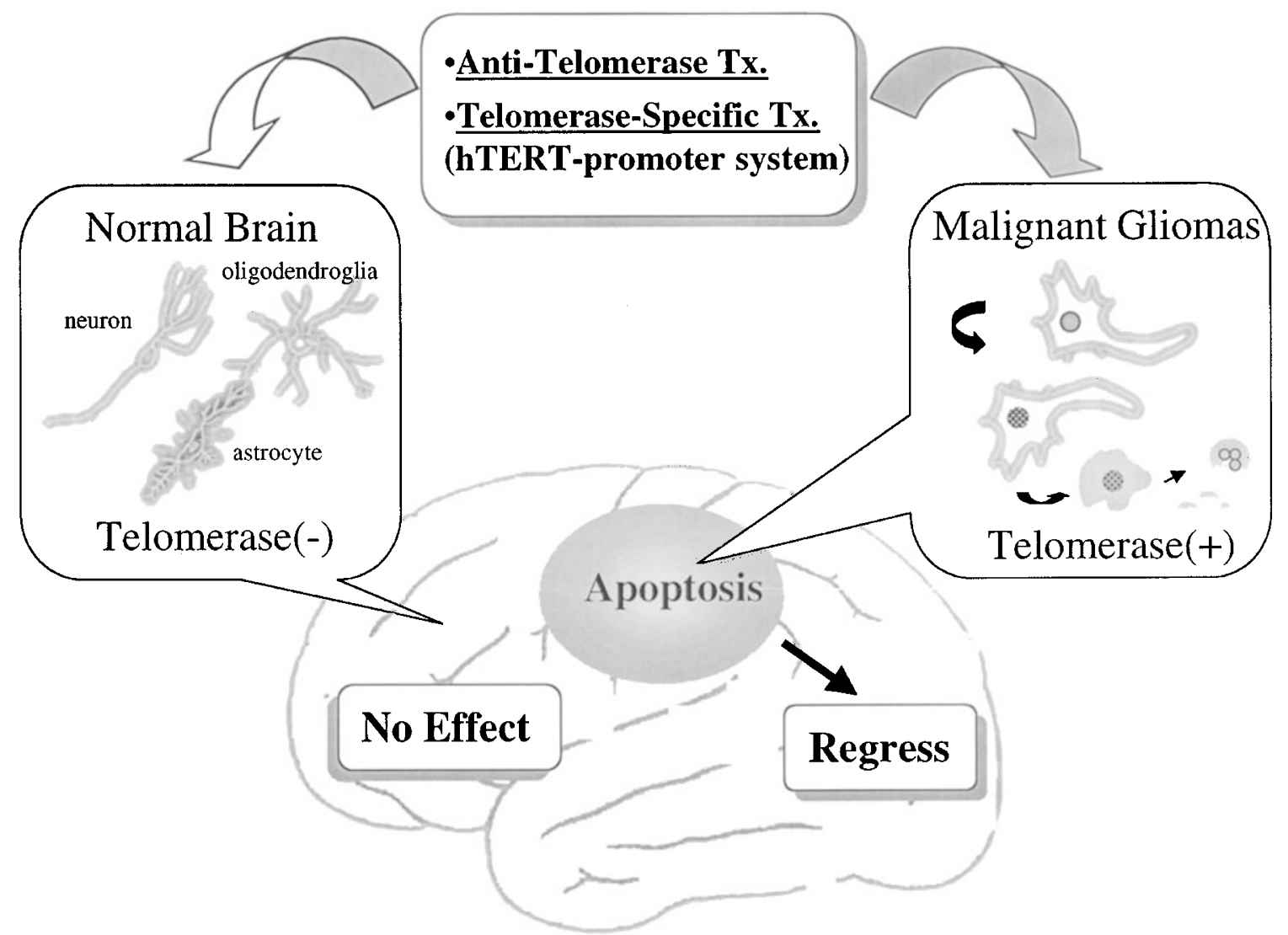

Figure 1 Schematic model of telomerase-associated therapies for malignant gliomas

\section{hTERT promoter system}

Utilization of a promoter that is predominantly active in tumor cells would be an ideal system to restrict the therapeutic gene expression. Telomerase is a particularly attractive target for specifying tumors, because approximately $90 \%$ of tumors have telomerase activity, whereas most normal cells do not express telomerase (Kim et al., 1994; Broccoli et al., 1995; Hiyama et al., 1995). In human cells, telomerase activity is regulated by transcriptional control of the hTERT gene whose product is the catalytic subunit of the enzyme (Meyerson et al., 1997; Nakamura et al., 1997). Certainly, the transcriptional activity of the hTERT gene promoter is significantly higher in telomerasepositive cells than in telomerase-negative cells (Takakura et al., 1999; Cong et al., 1999). Therefore, the feasibility of using the hTERT promoter to induce tumor-specific transgene expression in cancer gene therapy has been expected. Recent investigations have demonstrated that, by using the hTERT promoterdriven expression vector of therapeutic gene such as caspase- 8 , bax, diphtheria toxin A, thymidine kinase, rev-caspase-6, or FADD, the cytotoxic effect is restricted to telomerase-positive tumor cells of wide range (Koga et al., 2000, 2001b; Gu et al., 2000; AbduGhani et al., 2000; Majumdar et al., 2001; Komata et al., 2001). These results suggest that the hTERT promoter is a novel and promising tumor-selective promoter with potential application in targeted cancer gene therapy, although telomerase-positive normal cells may be damaged by the treatment.

\section{Immunotherapy}

If tumor-associated antigens that are universal to tumors of wide range are discovered, these antigens will be used to elicit effective immuno-response against the antigens-positive tumors. Telomerase or hTERT is considered a potential target for cancer immunotherapy because it is preferentially expressed in tumor cells, indicating it as the truly universal tumor antigen. In human systems, CD8 + cytotoxic T lymphocyte (CTL) specific for hTERT peptides and restricted to MHC HLA-A2 lysed hTERT + tumors from multiple histologies (Vonderheide et al., 1999; Minev et al., 2000). This CTL response was not shown in telomerasenegative cells, cells negative for the HLA-A2 (Vonderheide et al., 1999), or telomerase-positive CD34+ hematopoietic cells (Minev et al., 2000). Additionally, the CD8 + CTL clones specific for hTERT-derived peptides carrying motifs for HLA-A24 exerted cytotoxicty against leukemia cells in an HLA-A24-restricted manner (Arai et al., 2001). Furthermore, it has been demonstrated that induction of CTL responses and tumor immunity against unrelated tumors using TERT 
RNA-transfected dendritic cells (Nair et al., 2000). These findings suggest hTERT as a potentially important and widely applicable target for immunotherapy, although we need to investigate whether telomerase-positive normal cells will be affected by the CTL response.

\section{Potential problems with telomerase-specific cancer therapy}

Telomerase-specific cancer therapy is to kill telomeraseexpressing cells. This approach has the advantage of abolishing the time lag that is required with the vast majority of anti-telomerase cancer therapy. If the hTERT promoter system is systemically given, telomerase-positive normal cells such as stem cells or germline cells will undergo cell death. To increase the safety of this modality, local delivery may be a reasonable approach. It is also possible that similar side effects will occur in immunotherapy. Recently, it has been shown that immunization with tumor RNA was generally more effective than immunization with TERT RNA (Nair et al., 2000; Heiser et al., 2001). Therefore, an optimal immunization protocol may have to include TERT as well as additional tumor antigens.

\section{Future prospects for telomerase-associated treatment of malignant gliomas}

Because malignant gliomas are predominantly telomerase-positive in the central nervous system (CNS), they might be one of the best candidates for anti-telomerase or telomerase-specific cancer therapy. As shown in Figure 1, these approaches will display low toxicity and few side effects for patients with malignant gliomas if locally administered. It is because normal brain tissues are generally telomerase-negative and local administration of reagents will permit us to save extracranial tissues expressing telomerase from toxicity or side effects. With regard to the anti-telomerase cancer therapy, it is essential to keep the concentration of

\section{References}

Abdul-Ghani R, Ohana P, Matouk I, Ayesh S, Ayesh B, Laster M, Bibi O, Giladi H, Molnar-Kimber K, Sughayer MA, de Groot N and Hochberg A. (2000). Mol. Ther., 2, $539-544$.

Agrawal S, Jiang Z, Zhao Q, Shaw D, Cai Q, Roskey A, Channavajjala L, Saxinger C and Zhang R. (1997). Proc. Natl. Acad. Sci. USA, 94, 2620-2625.

Arai J, Yasukawa M, Ohminami H, Kakimoto M, Hasegawa A and Fujita S. (2001). Blood, 97, 2903-2907.

Betts L, Josey JA, Veal JM and Jordan SR. (1995). Science, 270, $1838-1841$.

Blackburn EH. (1991). Nature, 350, 569-573.

Broccoli D, Young JW and de Lange T. (1995). Proc. Natl. Acad. Sci. USA, 92, 9082-9086.

Burger PC, Vogel FS, Green SB and Strike TA. (1985). Cancer, 56, $1106-1111$. reagents of this therapy above a certain level in malignant gliomas. The application of pump systems such as osmotic minipumps combined with stereotaxic techniques (Zhu et al., 1996) will allow continuous delivery of therapeutic materials into the tumors. Additionally, the use of injectable and biodegradable sustained-release formulations such as polymer or microspheres (Johnson et al., 1997; Putney and Burke, 1998) may be promising. As for the telomerase-specific cancer therapy, local injection of hTERT promoter system carrying therapeutic genes using pumps or biodegradable materials is a reasonable approach as anti-telomerase cancer therapy. To treat malignant gliomas with immunotherapy against telomerase-positive cells, we need to determine whether telomerasepositive stem cells or germline cells are affected by the CTL response. Recent insights into the immunobiology of the CNS and malignant gliomas suggest that difficulties in immunotherapy may be mainly due to the following factors (Roth and Weller, 1999). (1) Presence of the blood-brain barrier (BBB) that functions to exclude elements of the immune system from the tumor or brain parenchyma, although it is partially disrupted by the tumor. (2) Lack of organized secondary lymphatic tissues supporting efficient immune response locally in the CNS. (3) Low level in MHC expression in the CNS. (4) An apparent paucity of the most efficient antigen-presenting cells (APCs). And (5) malignant glioma-derived immunosuppressive factors, such as transforming growth factor (TGF)- $\beta$, that interfere with the induction of local as well as systemic immune responses to the tumor. Recognition of these factors will permit us to establish novel immunotherapeutic approaches including hTERTbased immunotherapy.

\section{Acknowledgments}

Our research involving the development of $2-5 \mathrm{~A}$-antihTER and hTERT/caspase family systems is supported in part by the Cleveland Clinic Foundation Research Funds No. 5928 and No. 6200 (S Kondo), the John Gagliarducci Fund (S Kondo), and the NIH grants CA80233 and CA88936 (S Kondo).

Buzayan JM, Gerlach WL and Bruening G. (1986). Nature, 323, 349-353.

Carroll T, Maltby E, Brock I, Royds J, Timperley W and Jellinek D. (1999). J. Pathol., 188, 395-399.

Cech TR, Zaug AJ and Grabowski PJ. (1981). Cell, 27, $487-$ 496.

Chiu CP, Dragowska W, Kim NW, Vaziri H, Yui J, Thomas TE, Harley CB and Lansdorp PM. (1996). Stem Cells, 14, $239-248$.

Chong EYY, Lam PYP, Poon W-S and Ng H-K. (1998). Hum. Pathol., 29, 599-603.

Cong YS, Wen J and Bacchetti S. (1999). Hum. Mol. Genet., 8, $137-142$.

Counter CM, Avilion AA, LeFeuvre CE, Stewart NG, Greider CW, Harley CB and Bacchetti S. (1992). EMBO J., 11, $1921-1929$. 
Davis FG, McCarthy BJ, Freels S, Kupelian V and Bondy ML. (1999). Cancer, 85, 485-491.

Deen DF, Chiarado A, Grimm EA, Fike JR, Israel MA, Kun LE, Levin VA, Marton LJ, Packer RJ, Pegg AE, Rosenblum ML, Suit HD, Walker MD, Wikstrand CJ, Wilson CB, Wong AJ and Yung WKA. (1993). J. NeuroOncol., 16, 243-272.

de Lange T. (1994). Proc. Natl. Acad. Sci. USA, 91, $2882-$ 2885.

DeMasters BK, Markham M, Lillehei KO and Shroyer K. (1997). Am. J. Clin. Pathol., 107, 548-554.

Falchetti ML, Pallini R, Larocca LM, Verna R and D'Ambrosio E. (1999). J. Clin. Pathol., 52, 234-236.

Feng J, Funk WD, Wang SS, Weinrich SL, Avilion AA, Chiu CP, Adams RR, Chang E, Allsopp RC, Yu J, Le S, West MD, Harley CB, Andrews WH, Greider CW and Villeponteau B. (1995). Science, 269, 1236-1241.

Gilley D and Blackburn EH. (1996). Mol. Cell. Biol., 16, 6675.

Gu J, Kagawa S, Takakura M, Kyo S, Inoue M, Roth JA and Fang B. (2000). Cancer Res., 60, 5359-5364.

Hahn WC, Stewart SA, Brooks MW, York SG, Eaton E, Kurachi A, Beijersbergen RL, Knoll JHM, Meyerson M and Weinberg RA. (1999). Nature Med., 5, 1164-1170.

Harada K, Kurisu K, Tahara H, Tahara E, Ide T and Tahara E. (2000). J. Neurosurg., 93, 618-625.

Harrington L, McPhail T, Mar V, Zhou W, Oulton R, Bass MB, Arruda I and Robinson MO. (1997). Science, 275, 973-977.

Heiser A, Maurice MA, Yancey DR, Coleman DM, Dahm P and Vieweg J. (2001). Cancer Res., 61, 3388-3393.

Herbert B, Pitts AE, Baker SI, Hamilton SE, Wright WE, Shay JW and Corey DR. (1999). Proc. Natl. Acad. Sci. USA, 96, 14276 - 14281 .

Hiraga S, Ohnishi T, Izumoto S, Miyahara E, Kanemura Y, Matsumura H and Arita N. (1998). Cancer Res., 58, $2117-2125$.

Hiyama K, Hiyama E, Ishioka S, Yamakido M, Inai K, Gazdar AF, Piatyszek MA and Shay JW. (1995). J. Natl. Cancer Inst., 87, 895-902.

Huang F, Kanno H, Yamamoto I, Lin Y and Kubota Y. (1999). J. Neurooncol., 43, 137-142.

Johnson OL, Jaworowicz W, Cleland JL, Bailey L, Charnis M, Duenas E, Wu C, Shepard D, Magil S, Last T, Jones AJ and Putney SD. (1997). Pharm. Res., 14, 730-735.

Kanazawa Y, Ohkawa K, Ueda K, Mita E, Takehara T, Sasaki Y, Kasahara A and Hayashi N. (1996). Biochem. Biophys. Res. Commun., 225, 570-576.

Karlseder J, Broccoli D, Dai Y, Hardy S and de Lange T. (1999). Science, 283, $1321-1325$.

Kim NW, Piatyszek MA, Prowse KR, Harley CB, West MD, Ho PLC, Coviello GM, Wright WE, Weinrich SL and Shay JW. (1994). Science, 266, 2011-2015.

Kleinschmidt-DeMasters BK, Hashizumi TL, Sze C-I, Lillehei KO, Shroyer AL and Shroyer KR. (1998). J. Clin. Pathol., 51, 284-293.

Kleinschmidt-DeMasters BK, Evans LC, Bobak JB, LopezUribe D, Hopper D, Shroyer AL and Shroyer KR. (2000). Hum. Pathol., 31, 905-913.

Koga S, Hirohata S, Kondo Y, Komata T, Takakura M, Inoue M, Kyo S and Kondo S. (2000). Hum. Gene. Ther., 11, $1397-1406$.

Koga S, Kondo Y, Komata T and Kondo S. (2001a). Gene Ther., 8, 654-658.

Koga S, Hirohata S, Kondo Y, Komata T, Takakura M, Inoue M, Kyo S and Kondo S. (2001b). Anticancer Res., 21, 1937- 1943 .
Komata T, Kondo Y, Koga S, Ko SC, Chung LW and Kondo S. (2000). Gene Ther., 7, 2071-2079.

Komata T, Kondo Y, Kanzawa T, Hirohata S, Koga S, Sumiyoshi H, Srinivasula SM, Barna BP, Germano IM, Takakura M, Inoue M, Alnemri ES, Shay JW, Kyo S and Kondo S. (2001). Cancer Res., 61, 5796-5802.

Kondo S, Tanaka Y, Kondo Y, Hitomi M, Barnett GH, Ishizaka Y, Liu J, Haqqi T, Nishiyama A, Villeponteau B, Cowell JK and Barna BP. (1998a). FASEB J., 12, $801-$ 811.

Kondo S, Kondo Y, Li G, Silverman RH and Cowell JK. (1998b). Oncogene, 16, 3323-3330.

Kondo Y, Koga S, Komata T and Kondo S. (2000). Oncogene, 19, 2205-2211.

Kondo Y, Komata T and Kondo S. (2001). Int. J. Oncol., 18, $1287-1292$.

Kushner DM, Paranjape JM, Bandyopadhyay B, Cramer H, Leaman DW, Kennedy AW, Silverman RH and Cowell JK. (2000). Gynecol. Oncol., 76, 183-192.

Langford LA, Piatyszek MA, Xu R, Schold Jr SC and Shay JW. (1995). Lancet, 346, $1267-1268$.

Le S, Zhu JJ, Anthony DC, Greider CW and Black PM. (1998). Neurosurgery, 42, $1120-1125$.

Ludwig A, Saretzki G, Holm PS, Tiemann F, Lorenz M, Emrich T, Harley CB and von Zglinicki T. (2001). Cancer Res., 61, 3053-3061

Mahaley Jr MS, Mettlin C, Natarajan N, Laws Jr ER and Peace BB. (1989). J. Neurosurg., 71, 826-836.

Majumdar AS, Hughes DE, Lichtsteiner SP, Wang Z, Lebkowski JS and Vasserot AP. (2001). Gene Ther., 8, $568-578$.

Maran A, Maitra RK, Kumar A, Dong B, Xiao W, Li G, Williams BRG, Torrence PF and Silverman RH. (1994). Science, 265, $789-792$.

Melana SM, Holland JF and Pogo BG. (1998). Clin. Cancer Res., 4, 693-696.

Meyerson M, Counter CM, Eaton EN, Ellisen LW, Steiner P, Caddle SD, Ziaugra L, Beijersbergen RL, Davidpoff ML, Liu Q, Bacchetti S, Haber DA and Weinberg RA. (1997). Cell, 90, 785-795.

Minev B, Hipp J, Firat H, Schmidt JD, Langlade-Demoyen P and Zanetti M. (2000). Proc. Natl. Acad. Sci. USA, 97, 4796 - 4801 .

Mukai S, Kondo Y, Koga S, Komata T, Barna BP and Kondo S. (2000). Cancer Res., 60, 4461-4467.

Multani AS, Furlong C and Pathak S. (1998). Int. J. Oncol., 13, $923-925$.

Nair SK, Heiser A, Boczkowski D, Majumdar A, Naoe M, Lebkowski JS, Vieweg J and Gilboa E. (2000). Nat. Med., 6, $1011-1017$.

Nakamura TM, Morin GB, Chapman KB, Weinrich SL, Andrews WH, Linger J, Harley CB and Cech TR. (1997). Science, 277, 955-959.

Nakayama J, Saito M, Nakamura H, Matsuura A and Ishikawa F. (1997). Cell, 88, 875-884.

Norton JC, Piatyszek MA, Wright WE, Shay JW and Corey DR. (1996). Nat. Biotechnol., 14, 615-619.

Ostenfeld T, Caldwell MA, Prowse KR, Linskens MH, Jauniaux E and Svendsen CN. (2000). Exp. Neurol., 164, $215-226$

Piepmeier JM and Christopher S. (1997). J. Neurooncol., 34, $1-3$.

Pitts AE and Corey DR. (1998). Proc. Natl. Acad. Sci. USA, 95, $11549-11554$.

Putney SD and Burke PA. (1998). Nat. Biotechnol., 16, $153-$ 157. 
Ramakrishnan S, Eppenberger U, Mueller H, Shinkai Y and Narayanan R. (1998). Cancer Res., 58, 622-625.

Roth W and Weller M. (1999). Cell Mol. Life Sci., 56, 481 506.

Sallinen P, Miettinen H, Sallinen S-L, Haapasalo H, Helin H and Kononen J. (1997). Am. J. Pathol., 150, 1159-1164.

Sano T, Asai A, Mishima K, Fujimaki $\mathrm{T}$ and Kirino $\mathrm{T}$. (1998). Br. J. Cancer, 77, $1633-1637$.

Schoenberg BS. (1983). Walker MD (ed). Nijhoff, Boston, $1-30$.

Shammas MA, Simmons CG, Corey DR, Shmookler and Reis RJ. (1999). Oncogene, 18, 6191-6200.

Silverman RH. (1997). G D'Alessio and JF Riordan (ed). Academic Press, Inc., 515-551.

Strahl C and Blackburn EH. (1994). Nucleic Acids Res., 22, $893-900$

Strahl C and Blackburn EH. (1996). Mol. Cell. Biol., 16, $53-$ 65.

Takakura M, Kyo S, Kanaya T, Hirano H, Takeda J, Yutsudo M and Inoue M. (1999). Cancer Res., 59, $551-$ 557.

Tejera AM, Alonso DF, Gomez DE and Olivero OA. (2001). Breast Cancer Res. Treat., 65, 93-99.
Tzfati Y, Fulton TB, Roy J and Blackburn EH. (2000). Science, 288, $863-867$.

Vonderheide RH, Hahn WC, Schultze JL and Nadler LM. (1999). Immunity, 10, 673-679.

Weil RJ, Wu Y-Y, Vortmeyer AO, Moon Y-W, Delgado RM, Fuller BG, Lonser RR, Remaley AT and Zhuang Z. (1999). Mod. Pathol., 12, 41-46.

Weng NP, Levine BL, June CH and Hodes RJ. (1996). $J$. Exp. Med., 183, 2471-2479.

White LK, Wright WE and Shay JW. (2001). Trends Biotechnol., 19, 114-120.

Wright WE, Piatyszek MA, Rainey WE, Byrd W and Shay JW. (1996). Dev. Genet., 18, 173-179.

Yokoyama Y, Takahashi Y, Shinohara A, Lian Z, Wan X, Niwa K and Tamaya T. (1998). Cancer Res., 58, $5406-$ 5410.

Yokoyama Y, Takahashi Y, Shinohara A, Wan X, Takahashi S, Niwa K and Tamaya T. (2000). Biochem. Biophys. Res. Commun., 273, 316-321.

Zhang X, Mar V, Zhou W, Harrington L and Robinson MO. (1999). Gene Dev., 13, 2388-2399.

Zhu J, Zhang L, Hanisch UK, Felgner PL and Reszka R. (1996). Gene Ther., 3, $472-476$. 